\title{
First record of loggerhead sea turtles Caretta caretta in Sebastián Vizcaíno Bay, Baja California Peninsula, Mexico
}

\author{
Helena Fernández-Sanz ${ }^{1,2}$, Fabián Castillo Romero ${ }^{3}$, Joaquín Rivera Rodríguez ${ }^{3}$, Noé López Paz ${ }^{4}$ \\ Gabriel Arturo Zaragoza Aguilar ${ }^{4}$ \& Eduardo Reséndiz ${ }^{2,5}$ \\ ${ }^{1}$ Posgrado en Ciencias Marinas y Costeras, Universidad Autónoma de Baja California Sur \\ La Paz, B.C.S., México \\ ${ }^{2}$ Health Assessments in Sea Turtles from B.C.S., La Paz, B.C.S., México \\ ${ }^{3}$ Área de conservación ambiental y Gerencia de gestión integral y planeación de \\ Empresa Exportadora de Sal S.A., Guerrero Negro, B.C.S., México \\ ${ }^{4}$ Reserva de la Biosfera El Vizcaíno, Comisión Nacional de Áreas Naturales Protegidas \\ Guerrero Negro, B.C.S., México \\ ${ }^{5}$ Departamento Académico de Ciencias Marinas y Costeras, Universidad Autónoma de Baja California Sur \\ La Paz, B.C.S., México \\ Corresponding author: Helena Fernández-Sanz (helena.fdezsanz@ gmail.com)
}

\begin{abstract}
The loggerhead sea turtle (Caretta caretta) is an endangered species which distributes around the west coast of the Baja California Peninsula. In Baja California Sur, the conservation efforts for this species were focused in the Gulf of Ulloa; however, within the Pacific coast of the Baja California Peninsula, Sebastián Vizcaíno Bay (SVB) biological active center suit the optimal conditions for the presence of loggerheads. This study aimed to investigate SVB as a potential foraging area for loggerheads. Between July and August 2018, three prospective surveys were conducted, in search of marine turtles in SVB. A total of three loggerhead turtles and one eastern Pacific green turtle (Chelonia mydas) were captured; biometric data were recorded, and organisms were classified as juveniles. This is the first report of the loggerhead sea turtles in the SVB and given the oceanographic characteristics of the bay, it is a potential foraging and development area for the species.
\end{abstract}

Keywords: Caretta caretta; distribution; foraging area; biological active center; Guerrero Negro; Pacific coast

The loggerhead sea turtle (Caretta caretta) is a threatened species, which distributes throughout the tropical-subtropical regions of the Pacific, Atlantic, Indian Ocean and the Mediterranean Sea (Bowen et al., 1994). These highly migratory species travel between the same foraging and nesting areas throughout its lifetime; in the Pacific Ocean, they migrate from Japan and Australia nesting beaches across the ocean to the eastern Pacific where they spend several years foraging and maturing (Peckham et al., 2011). The central north Pacific, as well as the west coast of the Baja California Peninsula, represents important foraging sites for the loggerhead turtle populations, mainly in upwelling areas of high productivity (Polovina et al., 2006; Abecassis et al., 2013; Seminoff et al., 2014).

In Baja California Sur, all the conservation efforts for loggerheads have been focused in the Gulf of Ulloa (established as the main foraging hotspot for loggerhead sea turtles (Seminoff et al., 2014)) due to the high mortality associated with bycatch (Peckham et al., 2011). However, on the Pacific coast of the Baja California Peninsula, there is another area of high biological activity, Sebastián Vizcaíno Bay (SVB; Lluch-Belda, 2000). This bay consists of an extensive platform of igneous rock over the Pacific Plate located within the region of the California Current (Tsuchiya, 1982), where predominant northwest winds and the convergence of three major water masses (Central Pacific Water Mass, Eastern Tropical Pacific Water Mass, and Subarctic Water Mass) produce one of the main coastal upwelling regions (Bakun \& Nelson, 1977). The annual mean temperature is 18 to $20^{\circ} \mathrm{C}$, and rainfall is scarce with no freshwater sources (Wyllie, 1961). These characteristics lead to high rates of prima-

Corresponding editor: Joanna Alfaro 

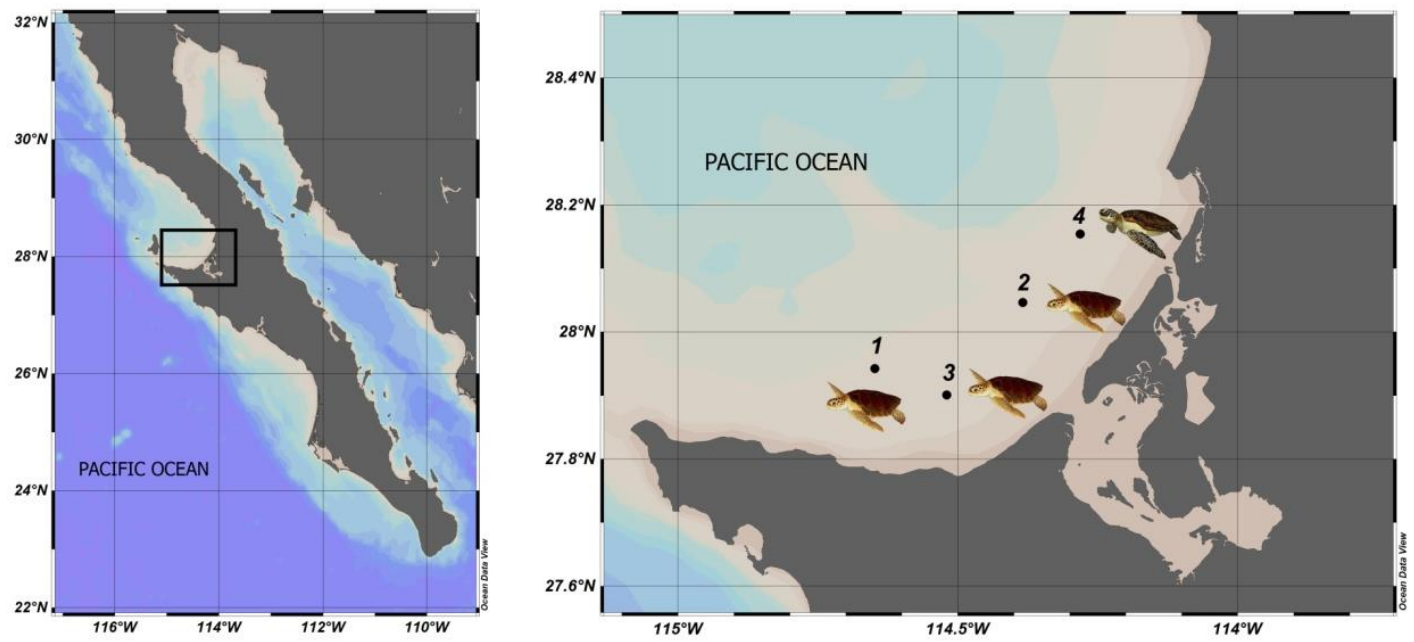

Figure 1. Location of the captured marine turtles Caretta caretta $(1,2,3)$ and Chelonia mydas (4).
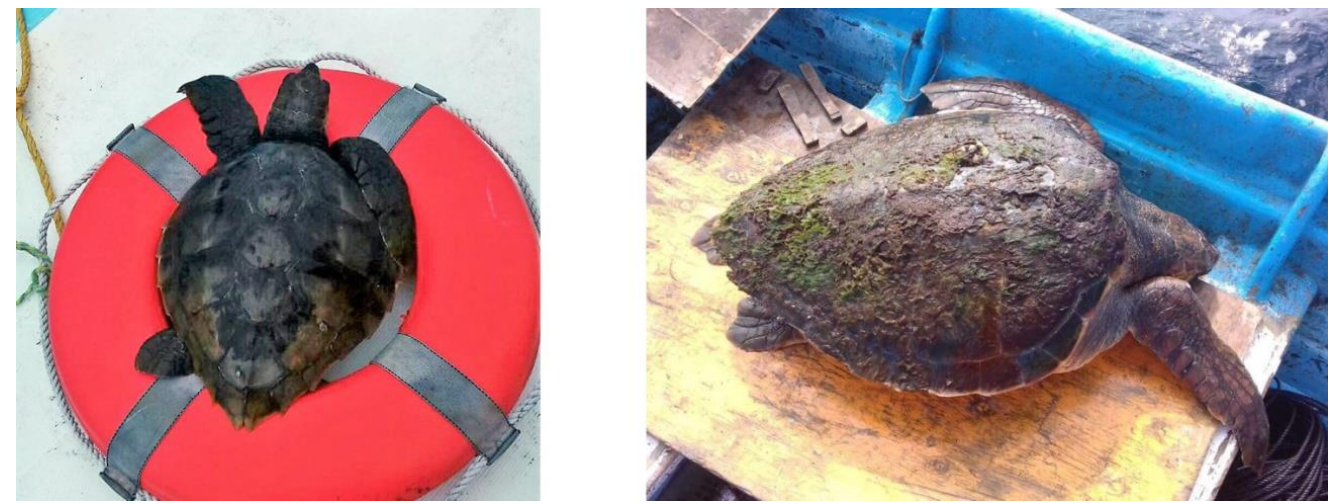

Figure 2. Juvenile loggerhead sea turtles (Caretta caretta) captured in Sebastián Vizcaíno Bay.

ry production (Hernández-Rivas et al., 2000), suggesting that the region could have optimal conditions for loggerhead sea turtles. The present study aimed to investigate the potential of SVB as a foraging area for loggerhead sea turtles.

The study was conducted around $28^{\circ} 23^{\prime}-27^{\circ} 48^{\prime} \mathrm{N}$ and $115^{\circ} 00^{\prime}-114^{\circ} 12^{\prime} \mathrm{W}$, SVB. Between July and August 2018, three prospective surveys were conducted in search of marine turtles on the Pacific coast of Guerrero Negro, SVB. The turtles were captured by hand modifying the rodeo-jumping technique proposed by Limpus (1978). Once on the boat, the curved caparace length (CCL) and weight were registered following Bolten's (1999) methodology; sex of the turtles was determined according to tail length sexual dimorphism described by Wyneken (2001). Organisms were tagged in the frontal flippers following Balazs's (1999) methodology using Monel tags. Finally, an individual photo-documented report for each of the turtles was prepared for their identification and further monitoring; immediately after, they were released. This research was conducted under the permit: OFICIO No. SGPA/DGVS/013214/18. A total of three loggerhead sea turtles and one eastern Pacific green turtle (EPGT; Chelonia mydas) were captured (Figs. 1-2); loggerheads under $91 \mathrm{~cm}$ (CCL) were considered juveniles according to the average size of Japanese nesters (Kamezaki et al., 1995, Hatase et al., 2004) and EPGTs under $77 \mathrm{~cm}$ (CCL) were considered juveniles according to Márquez (1990), as shown in Table 1.

The SVB host a large number of species both marine vertebrates and invertebrates, and has been selected as a Priority Marine Area by the Mexican Government because of its high biodiversity (Lluch-Belda, 2000); due to its oceanographic characteristics, it provides the optimal conditions as a marine turtle foraging site. Our surveys have been the first monitoring in the area, so basic features of the turtles are yet unknown, such as their reproductive dynamics, their use of habitat, distribution and movements, resting areas and health 
Table 1. Curved carapace length (CCL), weight, sex and coordinates of the captured turtles Caretta caretta and Chelonia mydas in the Sebastián Vizcaíno Bay. SD: standard deviation; U: Undefined.

\begin{tabular}{ccccccc}
\hline ID & Species & Date & CCL $(\mathrm{cm})$ & Weight $(\mathrm{kg})$ & Sex & Coordinates \\
\hline 1 & C. caretta & $11 / 07 / 2018$ & 38.6 & 12 & $\mathrm{U}$ & $27^{\circ} 56^{\prime} 32.0^{\prime \prime} \mathrm{N}, 114^{\circ} 38^{\prime} 53.7^{\prime \prime} \mathrm{W}$ \\
2 & C. caretta & $11 / 07 / 2018$ & 45.1 & 18 & $\mathrm{U}$ & $28^{\circ} 02^{\prime} 46.9^{\prime \prime} \mathrm{N}, 114^{\circ} 23^{\prime} 02.8^{\prime \prime} \mathrm{W}$ \\
3 & C. caretta & $14 / 08 / 2018$ & 82.6 & 52 & $\mathrm{U}$ & $27^{\circ} 54^{\prime} 03.6^{\prime \prime} \mathrm{N}, 114^{\circ} 31^{\prime} 12.2^{\prime \prime} \mathrm{W}$ \\
\cline { 3 - 7 } & & Mean \pm SD & $55.43 \pm 23.75$ & $27.33 \pm 21.57$ & & \\
\cline { 3 - 7 } 4 & C. mydas & $22 / 08 / 2018$ & 62.0 & 30 & $\mathrm{U}$ & $28^{\circ} 09^{\prime} 14.3^{\prime \prime} \mathrm{N}, 114^{\circ} 16^{\prime} 53.4^{\prime \prime} \mathrm{W}$ \\
\hline
\end{tabular}

conditions, among others. The generated information about behavior, foraging and resting areas in the Baja California Peninsula is still limited (Peckham et al., 2007), although it has been observed that turtles show high fidelity to their Baja California Sur sites (Seminoff et al., 2002; Koch et al., 2007; Reséndiz et al., 2018).

Ojo de Liebre lagoon complex, "El Vizcaíno" Biosphere Reserve, is located on the coast of the SVB region and constitutes the main EPGT foraging area of the Baja California Peninsula (Reséndiz et al., 2018). Within the lagoons, juvenile marine turtles develop until maturity, when they migrate to breeding and nesting areas (in the case of females), and finally return to the lagoons (Reséndiz et al., 2019); thus, SVB is likely an important transit area for EPGTs.

Isla de Cedros, located northwest of Punta Eugenia, works as a constriction barrier; the bay is an excellent refuge for different species of marine turtles. In addition, the area is a great feeding source for organisms (Hernández-Rivas et al., 2000) being a potential foraging and development area for loggerhead sea turtles, since crayfish (Pleuroncodes planipes), abundant in the bay, has been reported as their main diet prey (Peckam et al., 2008). Our findings indicate that loggerhead sea turtles distribute within areas of the Baja California Peninsula other than the Gulf of Ulloa, highlighting the importance of including these new areas in future conservation and monitoring programs.

"El Vizcaíno" Biosphere Reserve, along with the Empresa Exportadora de Sal S.A., the project Health Assessments in Sea Turtles from B.C.S. and Universidad Autónoma de Baja California Sur, are concentrating efforts to carry out marine turtle conservation monitoring in SVB, intended to generate basic research and information of EPGTs and loggerhead sea turtles that distribute within the bay. This information will allow the generation, together with the corresponding local authorities, of mana-gement plans and appropriate conservation strategies to benefit the organisms and ecosystems in the SVB.

\section{ACKNOWLEDGMENTS}

Authors want to thank Everardo Mariano Meléndez, Oscar Javier Salazar Méndez and Rafael Buelna Grado from "El Vizcaíno" Biosphere Reserve-Comisión Nacional Áreas Naturales Protegidas (REBIVICONANP); Aarón Sánchez Castillo and Antonio Zaragoza Aguilar from Área de Conservación Ambiental and Gerencia de Gestión Integral y Planeación, Empresa Exportadora de Sal S.A. (ESSA) for their assistance and logistics during fieldwork. Dra. Mónica Lara-Uc and Dr. Juan Manuel López-Vivas from Universidad Autónoma de Baja California Sur (UABCS). This work was supported by the ESSA and REBIVI-CONANP.

\section{REFERENCES}

Abecassis, M., Senina, I., Lehodey, P., Gaspar, P., Parker, D., Balazs, G. \& Polovina, J. 2013. A model of loggerhead sea turtle (Caretta caretta) habitat and movement in the oceanic north Pacific. Plos One, 8: e73274.

Bakun, A. \& Nelson, C.S. 1977. Climatology of upwelling related processes off Baja California. California Cooperative Oceanic Fisheries Investigations, 19: 107-127.

Balazs, G. 1999. Factors to consider in the tagging of sea turtles. In: Eckert, K., Bjorndal, K., Abreu-Grobois, A. \& Donnelly, M. (Eds.). Research and management techniques for the conservation of sea turtles. IUCN/SSC Marine Turtle Specialist Group, Publication $N^{\circ} 4$.

Bolten, A. 1999. Techniques for measuring sea turtles. In: Eckert, K., Bjorndal, K., Abreu-Grobois, A. \& Donnelly, M. (Eds.). Research and management techniques for the conservation of sea turtles. IUCN/ SSC Marine Turtle Specialist Group, Publication $\mathrm{N}^{\circ} 4$.

Bowen, B.W., Kamezaki, N., Limpus, C.J., Hughes, G.R., Meylan, A.B. \& Avise, J.C. 1994. Global phylogeography of the loggerhead turtle (Caretta caretta) as indicated by mitochondrial DNA haplotypes. Evolution, 48(6): 1820-1828. 
Hatase, H., Matsuzawa, Y., Sato, K., Bando, T. \& Goto, K. 2004. Remigration and growth of loggerhead turtles (Caretta caretta) nesting on Senri Beach in Minabe, Japan: life-history polymorphism in a sea turtle population. Marine Biology, 144: 807-811.

Hernández-Rivas, M.E., Jiménez-Rosenberg, S.P., FunesRodríguez, R. \& Saldierna-Martínez, R.J. 2000. El centro de actividad biológica de la bahía de Sebastían Vizcaíno, una primera aproximación. In: Lluch-Belda, D., Elorduy-Garay, J., Lluch-Cota, S.E. \& Ponce-Díaz, G. (Eds.). BAC Centros de Actividad Biológica del Pacífico mexicano. Centro de Investigaciones Biológicas del Noroeste, Centro Interdisciplinario de Ciencias Marinas \& Consejo Nacional de Ciencia y Tecnología, La Paz, B.C.S., pp. 65-85.

Kamezaki, N., Goto, K., Matsuzawa, Y., Nakajima, Y., Omuta, K. \& Sato, K. 1995. Carapace length and width of the loggerhead turtle Caretta caretta nesting on the coast of Japan. Umigame Newsletter Japan, 26: 12-13.

Koch, V., Brooks, L.B. \& Nichols, W.J. 2007. Population ecology of the green/black turtle (Chelonia mydas) in Bahía Magdalena, Mexico. Marine Biology, 153(1): 35-46.

Limpus, C.J. 1978. The reef: uncertain land of plenty. In: Lavery, H.J. (Ed.). Exploration north - a natural history of Queensland. Lloyd O'Neill Pty Ltd., Sydney.

Lluch-Belda, D. 2000. Centros de actividad biológica en la costa occidental de Baja California. In: Lluch-Belda, D., Elorduy-Garay, J., Lluch-Cota, S.E. \& Ponce-Díaz, G. (Eds.). BAC Centros de actividad biológica del Pacífico mexicano. Centro de Investigaciones Biológi-cas del Noroeste, Centro Interdisciplinario de Ciencias Marinas \& Consejo Nacional de Ciencia y Tecnología, La Paz, B.C.S., pp. 49-64.

Márquez, R. 1990. Sea turtles of the world. An annotated and illustrated catalog of sea turtle species known to date. FAO Species Catalogue, 11(125): $81 \mathrm{pp}$.

Peckham, H., Maldonado, D., Walli, A., Ruiz, G. \& Crowder, L. 2007. Small-scale fisheries bycatch jeopardizes endangered Pacific loggerhead turtles. Plos One, 2(10): e1041. doi: 10.1371/journal. pone. 0001041

Peckham, H., Maldonado-Díaz, D., Koch, V., Mancini, A., Gaos, A. \& Tinker, M. 2008. High mortality of loggerhead turtles due to bycatch, human consumption, and strandings at Baja California Sur, Mexico, 2003 to 2007. Endanger Species Research, 5(2): 171-183.

Received: 25 March 2019; Accepted: 25 August 2019
Peckham, H., Maldonado-Diaz, D., Tremblay, Y., Ochoa, R., Polovina, J., Balazs, G., Dutton, P.H. \& Nichols, W.J. 2011. Demographic implications of alternative foraging strategies in juvenile loggerhead turtles Caretta caretta of the North Pacific Ocean. Marine Ecology Progress Series, 425: 269-280.

Polovina, J., Uchida, I., Balazs, G.H., Howell, E.A., Parker, D. \& Dutton, P.H. 2006. The Kuroshio extension bifurcation region: a pelagic hotspot for juvenile loggerhead sea turtles. Deep-Sea Research, 53: 326-339.

Reséndiz, E., Fernández-Sanz, H. \& Lara-Uc, M.M. 2018. Baseline health indicators of eastern Pacific green turtles (Chelonia mydas) from Baja California Sur, Mexico. Comparative Clinical Pathology, 27(5): 13091320.

Reséndiz, E., Fernández-Sanz, H., Ramos, D., LuceroSilva, V., Barrientos-Torres, D.S. \& Lara-Uc, M.M. 2019. Determinación de nuevos ingredientes en la dieta de tortugas verdes del Pacífico oriental (Chelonia mydas) de Baja California Sur, Mexico. In: Cuevas Flores, E.A., Guzmán Hernández, V., Guerra Santos, J.J. \& Rivas Hernández, G.A. (Eds.). El uso del conocimiento de las tortugas marinas como herramienta para la restauración de sus poblaciones y hábitats asociados México. Universidad Autónoma del Carmen, Ciudad del Carmen, pp. 285-290.

Seminoff, J.A., Resendiz, A. \& Nichols, W.J. 2002. Home range of green turtles Chelonia mydas at a coastal foraging area in the Gulf of California, Mexico. Marine Ecology Progress Series, 242: 253265.

Seminoff, J.A., Eguchi, T., Carretta, J., Allen, C.D., Prosperi, D., Rangel, R., Gilpatrick, J.W., Forney, K. \& Peckham, S.H. 2014. Loggerhead sea turtle abundance at a foraging hotspot in the eastern Pacific Ocean: implications for at-sea conservation. Endanger Species Research, 24(3): 207-220.

Tsuchiya, M. 1982. On the Pacific upper-water circulation. Journal of Marine Research, 40: 777-799.

Wyllie, J.G. 1961. The water masses of Sebastian Vizcaino Bay. California Cooperative Oceanic Fisheries, 8: 8393.

Wyneken, J. 2001. The anatomy of sea turtles. U.S. Department of Commerce, NOAA Technical Memorandum NMFS-SEFSC, 172 pp. 